\title{
INVESTIGATION OF RDE THERMAL PARAMETERS CHANGES IN RESPONSE TO LONG-TERM STATION BLACK OUT
}

\author{
Hendro Tjahjono \\ Center for Nuclear Reactor Technology and Safety, BATAN \\ Puspiptek Area Serpong, Tangerang Selatan-15314 \\ Email: hendro@batan.go.id, Fax: 021-7560913 \\ Diterima editor: 23 Februari 2017 \\ Diperbaiki: 20 April 2017 \\ Disetujui untuk publikasi: 25 April 2017
}

\begin{abstract}
INVESTIGATION OF RDE THERMAL PARAMETERS CHANGES IN RESPONSE TO LONGTERM STATION BLACK OUT. Due to long-term station black out (SBO) of the RDE (Experimental Power Reactor), the residual heat from the core will be removed to a residual heat removal system (RHRS). The objective of this study is to know the transient characteristic of RDE thermal parameters in response to the loss of residual heat removing ability for long-term. To achieve this objective, an analysis model of reactor thermal parameters changes during SBO, using Matlab program to simulate heat transfer equations of conduction, convection and radiation has been performed. Using this program, the changes of RDE thermal parameters until 800 hours after reactor trip have been analyzed. It is concluded that, in long-term SBO condition, the reactor is still safe with the maximum core temperature of $1140^{\circ} \mathrm{C}$, which is still far under the safety limit of $1600^{\circ} \mathrm{C}$ as stated in the design criteria. More attentions are needed to be taken with the increasing of concrete temperature up to $600^{\circ} \mathrm{C}$ when the water storage is empty. Therefore, the availability of water in the RHRS shall absolutely be maintained.
\end{abstract}

Keywords: experimental power reactor, residual heat removal, transient, Matlab.

\begin{abstract}
ABSTRAK
INVESTIGASI PERUBAHAN PARAMETER TERMAL RDE PADA KONDISI KEHILANGAN CATU DAYA LISTRIK DALAM JANGKA PANJANG. Akibat kehilangan catu daya listrik luar pada Reaktor Daya Eksperimental (RDE), panas sisa dari reaktor dibuang ke suatu sistem pembuang panas sisa. Penelitian ini bertujuan untuk mengetahui karakteristik transien parameter termal RDE ketika terjadi kegagalan pembuangan kalor sisa tersebut dalam jangka panjang. Untuk mencapai tujuan tersebut telah disusun model analisis perubahan parameter termal reaktor ketika terjadi Station Black Out (SBO) menggunakan pemrograman Matlab dengan melibatkan persamaan-persamaan perpindahan kalor secara konduksi, konveksi dan radiasi. Dengan menggunakan program ini perubahan parameter termal RDE hingga 800 jam setelah reaktor trip telah dianalisis. Disimpulkan bahwa pada kondisi SBO dalam jangka panjang tersebut, reaktor masih tetap aman dengan temperatur maksimum teras sebesar $1140{ }^{\circ} \mathrm{C}$, yaitu masih jauh di bawah batas aman $1600{ }^{\circ} \mathrm{C}$ yang telah ditetapkan dalam kriteria desain. Perlu diperhatikan adanya peningkatan temperatur beton hingga $600{ }^{\circ} \mathrm{C}$ jika air pendingin sudah habis. Oleh karena itu, ketersediaan air pendingin di sistem pembuang panas sisa mutlak harus dijaga.
\end{abstract}

Kata kunci: reaktor daya eksperimental, pembuang panas sisa, transien, Matlab. 


\section{INTRODUCTION}

Reaktor Daya Eksperimental (RDE) is an experimental power reactor which is planned to be built in Puspiptek area, South Tangerang City, Banten Province. The type of the reactor is High Temperature Reactor (HTR) with the thermal power of $10 \mathrm{MW}$ using pebble bed fuel elements, the same type as AREVA-HTR from France [1]. In the case of loss of all electrical power supply or usually called as Station Black Out (SBO) that will cause the loss of cooling flow followed by the reactor trip, the residual heat including decay heat will be removed by a safety feature called Residual Heat Removal System (RHRS) [2-5]. This feature removes the residual heat from the reactor core to a cavity cooling panel through conduction in the core, reflector and reactor vessel, and by radiation from external surface of reactor vessel to cavity cooling panel. In the cavity cooling panel, the heat will be transferred by natural convection in water to the water storage tank located above the panel. In the case of long-term SBO, it is possible that the water in the storage is totally lost by evaporation. So, the decay heat that is not absorbed any more by the cavity cooling panel will be absorbed by the concrete wall. Increasing temperature of concrete will decrease its strength, therefore, it is important to evaluate how high the concrete temperature will increase after the totally loss of storage water following SBO. Li Fu et.al. have analyzed the dynamic operation performance and safety characteristics of HTR-PM reactor during long-term depressurized loss of forced cooling accident (DLOFC). It could be shown that its RHRS was able to withstand maximum temperatures of reactor remaining below the allowable limits of $1600{ }^{\circ} \mathrm{C}[6]$.

The objective of this study is to evaluate the transient characteristic of RDE thermal parameters following the long-term SBO. The thermal parameters changes during SBO to be evaluated are as follows: the temperature distribution across the core and other reactor components, the influence of the water volume in RHRS to the reactor temperature, the influence of the concrete wall thickness against temperature and the heat power evacuated from each component of the reactor.

Using RDE design data and physical properties data of HTR-Module reactor as the main reference of RDE [7], this research work is an analysis model to calculate the reactor thermal parameters in transient condition. Using this model, a calculation program using Matlab has been developed. The program is made in cylindrical coordinate using implicite numerical scheme. The program is composed of two parts, i.e. calculation program in steady condition and calculation program in transient condition that was used to simulate the conduction equation in a function of radius and time. The numerical method utilized in this program is the finite difference method. Once the program is completed, SBO accident simulation is then done in two steps, simulation in steady state to obtain the temperature profile of reactor in normal operation condition, and the simulation in transient condition after SBO in a long time period. In this study, the simulation time was taken until 800 hours by investigating thermal parameters changes of the reactor especially those are important for safety evaluation.

\section{THEORY}

In the core of RDE during SBO there are three heat transfer mechanisms such as conduction and radiation within and between the pebble bed fuel elements, conduction in the reflector and the pressure vessel, and radiation from the external surface of pressure vessel to the cavity cooling panel [8]. The natural convection by the helium gas and radiation among the surface of the fuel elements are modeled as conduction together with the conduction inside the fuel elements. Therefore, the heat transfer mechanism in the reactor core could be still modeled as conduction with certain appropriate equivalent thermal conductivity with accomodating the radiation and convection $[9,10]$. According to the relatively high ratio between the height and the diameter, the axial heat transfer in this study is ignored. Thus, in overall parts of the reactor, from the core to the surface of concrete, it is applied the transient conduction equation in one dimension with the variables are time $t$ and radius $r$ in the following form $[11,12]$. 


$$
\frac{1}{r} \frac{\partial}{\partial r}\left(r \frac{\partial T}{\partial r}\right)+\frac{q}{k}=\frac{1}{\alpha} \frac{\partial T}{\partial t}
$$

with variable $r$ is radius $(\mathrm{m}), \mathrm{q}$ is power density $\left(\mathrm{W} / \mathrm{m}^{3}\right), \mathrm{k}$ is thermal conductivity $\left(\mathrm{W} / \mathrm{m}^{\circ} \mathrm{C}\right), \alpha$ is the thermal diffusivity $\left(\mathrm{m}^{2} / \mathrm{s}\right)$, T is parameter of temperature $\left({ }^{\circ} \mathrm{C}\right)$ and $\mathrm{t}$ is time variable $(\mathrm{s})$. This equation is then discritized using finite difference method in the scheme of implicite with the segment of $\Delta \mathrm{r}$ and the time step of $\Delta \mathrm{t}$.

If $i$ is the sequence number radius and $j$ is the sequence number of time, the discritization to the equation (1) gives, for the left side,

$$
\frac{1}{r} \frac{\partial}{\partial r}\left(r \frac{\partial T}{\partial r}\right)+\frac{q}{k}=\frac{1}{R_{i}} \frac{0,5\left(R_{i}+R_{i+1}\right)\left(\frac{T_{i+1, j}-T_{i, j}}{\Delta r}\right)-0,5\left(R_{i}+R_{i-1}\right)\left(\frac{T_{i, j}-T_{i-1, j}}{\Delta r}\right)}{\Delta r}+\frac{q_{i, j-1}}{k_{i, j-1}}
$$

and for the right side,

$$
\frac{1}{\propto} \frac{\partial T}{\partial t}=\frac{1}{\alpha_{i, j-1}} \frac{T_{i, j}-T_{i, j-1}}{\Delta t}
$$

By introducing those Equation 2 and 3 to the Equation 1, it is obtained

$$
\frac{0,5\left(R_{i}+R_{i+1}\right)\left(\frac{T_{i+1, j}-T_{i, j}}{\Delta r}\right)-0,5\left(R_{i}+R_{i-1}\right)\left(\frac{T_{i, j}-T_{i-1, j}}{\Delta r}\right)}{\Delta r}+\frac{q_{i, j-1}}{k_{i, j-1}}=\frac{1}{\alpha_{i, j-1}} \frac{T_{i, j}-T_{i, j-1}}{\Delta t}
$$

Using implicite scheme, therefore all values of temperature that are defined in the time step $j$, is accumulated in the left side of equation, and all physical properties are defined in the step of (j-1) and in the radius number of $i$. The temperature $T_{i, j-1}$ means the temperature in the radius $R i$ that has been obtained in the previous step of iteration. By accumulating those parameters, $\mathrm{q}_{\mathrm{i}, \mathrm{j}-1}, \mathrm{k}_{\mathrm{i}, \mathrm{j}-1}$ and, $\mathrm{k}_{\mathrm{i}, \mathrm{j}-1}$ in the right side of the equation, it is obtained

$$
\frac{0,5\left(R_{i}+R_{i+1}\right)\left(\frac{T_{i+1, j}-T_{i, j}}{\Delta r}\right)-0,5\left(R_{i}+R_{i-1}\right)\left(\frac{T_{i, j}-T_{i-1, j}}{\Delta r}\right)}{\Delta r}-\frac{T_{i, j}}{\alpha_{i, j-1} \Delta t}=-\frac{q_{i, j-1}}{k_{i, j-1}}-\frac{1}{\propto_{i, j-1}} \frac{T_{i, j-1}}{\Delta t}
$$

This equation forms a linear equation system in temperature of all radius Ri in the time step $\mathrm{j}$.

In addition, this equation is applied separately to each part of the reactor such as the core, the reflector, the pressure vessel, the cavity, and the concrete wall, with applying these boundary conditions in each proximity:

- The boundary condition of no heat transfer in the center of the core:

$$
\frac{\partial T}{\partial r}=0
$$

- The continuity of heat flux in the concrete surface is reprensented by Equation 7:

$$
-k_{b} \frac{\partial T}{\partial r}=h\left(T_{p}-T_{u d}\right)
$$

with $\mathrm{k}_{\mathrm{b}}$ is thermal conductivity of the concrete $\left(\mathrm{W} / \mathrm{m}^{\circ} \mathrm{C}\right)$ and $\mathrm{h}_{\mathrm{b}}$ is heat transfer coefficient on the concrete surface $\left(\mathrm{W} / \mathrm{m}^{2}{ }^{\circ} \mathrm{C}\right)$

- The continuity of heat flux in each border between to parts is represented by the following equation:

$$
k_{1} \frac{\partial T_{1}}{\partial r}=k_{2} \frac{\partial T_{2}}{\partial r}
$$

with $\mathrm{k}_{1}$ and $\mathrm{k}_{2}$ are the thermal conductivity of part 1 and part 2 .

In the cavity, actually the heat transfer mechanism is done by radiation and convection. For radiation, with the emmissivity coefficient of $\varepsilon$ and the Stefan Boltzmann constant of $\sigma$, it could be formulated the heat transfer coefficient equivalent of convection between the two surfaces as:

$$
h_{R}=\varepsilon \sigma\left(T_{1}{ }^{3}+T_{1}{ }^{2} T_{2}+T_{1} T_{2}{ }^{2}+T_{2}{ }^{3}\right)
$$

So, if it is added to the heat transfer coefficient by convection $h_{C}$ of the cavity, it is obtained the heat transfer coefficient equivalent in the cavity as

$$
h_{R C}=h_{R}+h_{C}
$$

The heat transfer coefficient by convection $\mathrm{h}_{\mathrm{C}}$ is defined as follows

$$
h_{C}=\frac{N u_{L} \cdot k_{u d}}{L}
$$


with $\mathrm{k}_{\mathrm{ud}}$ is the thermal conductivity of the air inside the cavity $\left(\mathrm{W} / \mathrm{m}^{\circ} \mathrm{C}\right), \mathrm{L}$ is the width of the cavity (m), and $\mathrm{Nu}$ is the average Nusseltz number that can be estimated using the correlation proposed by Catton [13] as shown in Equation 12.

$$
N u_{L}=0.22\left(\frac{P r}{0.2+P r} R a_{L}\right)^{0.28}\left(\frac{H}{L}\right)^{-1 / 4}
$$

with $\mathrm{H}$ is the height of the cavity (m), Pr is the Prandl number of the air and $\mathrm{Ra}_{\mathrm{L}}$ is the Rayleigh number that is defined as follows

$$
R a_{L}=\frac{g \beta \Delta T L^{3}}{\vartheta \alpha}
$$

with $g$ is the acceleration of gravity $\left(\mathrm{m} / \mathrm{s}^{2}\right), \beta$ is the thermal expansion of the air $(1 / \mathrm{K}), v$ is the kinematic viscosity of the air $\left(\mathrm{m}^{2} / \mathrm{s}\right), \alpha$ is the thermal diffusivity of the air $\left(\mathrm{m}^{2} / \mathrm{s}\right)$, and $\Delta \mathrm{T}$ is the temperature difference between the two sides of the cavity $\left({ }^{\circ} \mathrm{C}\right)$.

In considering the cavity as a media of conduction to be included in the equation of conduction as shown in Equation 1, it is needed to define the equivalent thermal conductivity $\mathrm{k}_{\mathrm{e}}$ in the cavity. This conductivity is taken in such a way to get the same temperature difference between the two proximities of the cavity, such as

$$
k_{e} \frac{\Delta T}{L}=h_{R C} \Delta T
$$

So by eliminating the $\Delta \mathrm{T}$ in the both sides of Equation 14, it obtains

$$
k_{e}=h_{R C} \times L
$$

\section{METHODOLOGY}

Vertical section of the reactor system to be analyzed is modeled in the schematic diagram shown in Figure 1. The RHRS removes the decay heat through conduction mechanism in the core and the reflector until it reaches the walls of the reactor vessel, then through the radiation from the surface of the vessel wall to the heat absorber panel and then passed through a natural circulation loop (thermo syphon mechanism) into the environment [14]. The cold side of this loop is a storage tank filled with water which is cooled by force convection through a heat exchanger which is then passed to a cooling tower.

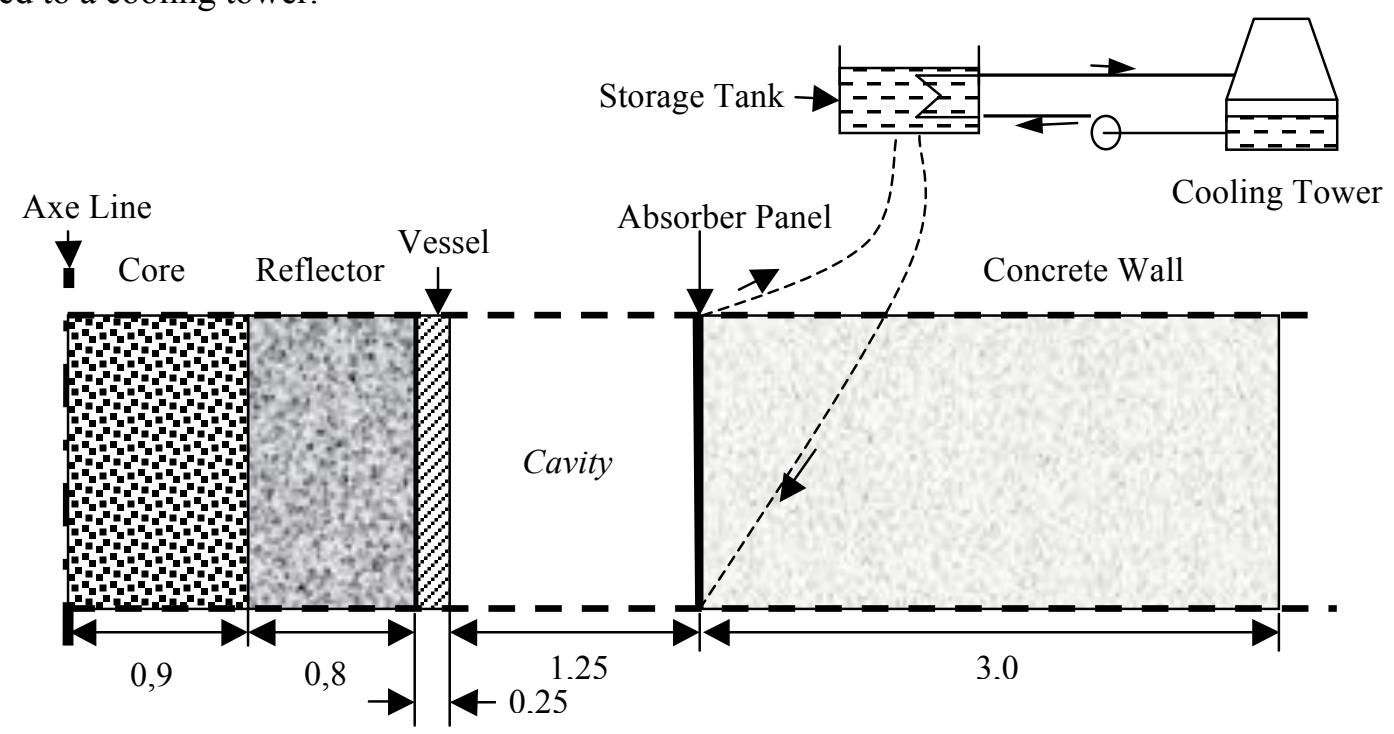

Figure 1. Schematic diagram of reactor system analysis model

When SBO is happened, the cooling water that flows in the tank will stop and continue naturally with much lower heat transfer coefficient. It is estimated that the cooling water temperature will rise until it reaches the boiling point that will cause a reduction in the amount of 
cooling water. The totally loss of cooling water will result in drastically loss of the capabilities in removing the decay heat from RHRS.

By using the RDE design data, an analysis model of core thermal parameters in transient condition after SBO based on Matlab program has been described. After finishing the program, the simulation of SBO accident has been done by investigating the reactor thermal parameters especially that are important for safety evaluation. The calculation program using Matlab is divided by two steps, such as:

- Firstly, steady state calculation, by using the conduction equation in cylindrical coordinates without the time variable. The objective of this calculation is to get the temperature distribution data of reactor in operation condition before beginning of the SBO accident. In this steady calculation, the power density is choosen in such a way the maximum temperature of the core is around $800^{\circ} \mathrm{C}$.

- Secondly, the calculation of the transient condition by solving numerically the equation of conduction including the time variable as shown in Equation 1. In this calculation, it was firstly defined the time step used. If the time step is short, the result is more accurate but it consumes longer computing time, therefore the optimal time step is necessary to be evaluated. In this study, the decay heat as a function of time is calculated using the formulation that has been used for RDE conceptual design. It is obtained by assuming the RDE operation time of 1 year. To obtain the condition without cooling water for long period of time, the calculation was done until 800 hours after shutting down the reactor.

As variable used in this study, in addition to the space variable $r$ and the time variable $t$, the initial volume of water in the storage tank and the thickness of concrete wall are also varied. The water volume is varied from $5 \mathrm{~m}^{3}$ to $20 \mathrm{~m}^{3}$, and the concrete thickness is varied from $0.3 \mathrm{~m}$ to $3 \mathrm{~m}$.

\section{RESULTS AND DISCUSSION}

The radial temperature distribution across the reactor components from the core to the concrete, for different times starting from the normal operation condition until 800 hours after SBO is shown in Figure 2. The maximum temperature in the normal operation condition is $800{ }^{\circ} \mathrm{C}$ as expected by design. This temperature has been achieved with the reactor heat power removed radially of $32 \mathrm{~kW}$. In SBO condition, all residual heat including decay heat has been removed radially to the RHRS because all active cooling mechanism is stopped then followed by reactor trip. The power produced in the condition of reactor trip is decay heat that remains great enough to increase the temperature of the core and the other components of the reactor such as: reflector, pressure vessel, heat absorber panel, and concrete wall. In the absorber panel it is shown that in the period of $20 \mathrm{~h}$ to $100 \mathrm{~h}$, the temperature is constant at $100^{\circ} \mathrm{C}$, it means that the water is in saturated condition. After totally loss of water, the temperature of the panel increases rapidly until $600{ }^{\circ} \mathrm{C}$ at 800 hours after reactor trip, followed by increasing the concrete temperature. Even though the temperature of other reactor components continues increasing with time, the maximum temperature of the core is inversely decreasing after reaching the maximum temperature of $1140{ }^{\circ} \mathrm{C}$ at 12 hours after reactor trip. Comparing to the results of Dwi Irwanto and Toru Obara study concerning the pebble bed reactor of $110 \mathrm{MW}$ which reaches the maximum core temperature of $1287^{\circ} \mathrm{C}$ at 32 hours after reactor shut down caused by the loss of active cooling flow [15], so those temperature patterns obtained in this study are comparable. 


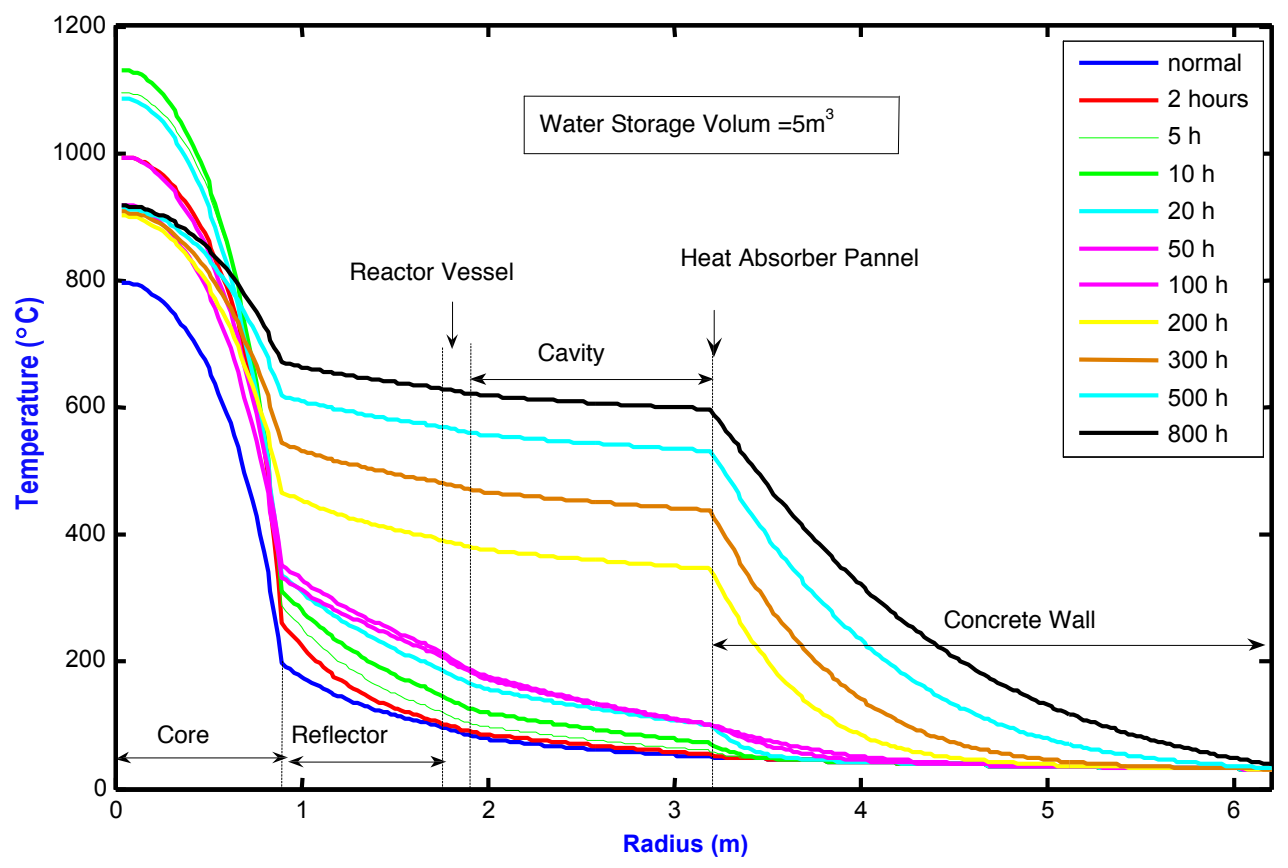

Figure 2. Radial temperature distribution across the reactor components starting from normal operation condition to 800 hours after SBO for the water volume of $5 \mathrm{~m}^{3}$.

Figure 3 shows the same temperature distribution for the volume of water in the storage of $20 \mathrm{~m}^{3}$. It is shown that with the much larger volume of water, the temperature of reactor components other than the core is still relatively low until the time of 500 hours. The increasing temperature is just observed at the time of 800 hours. It is shown that the amount of water in the storage takes the important role in delaying the temperature increase.

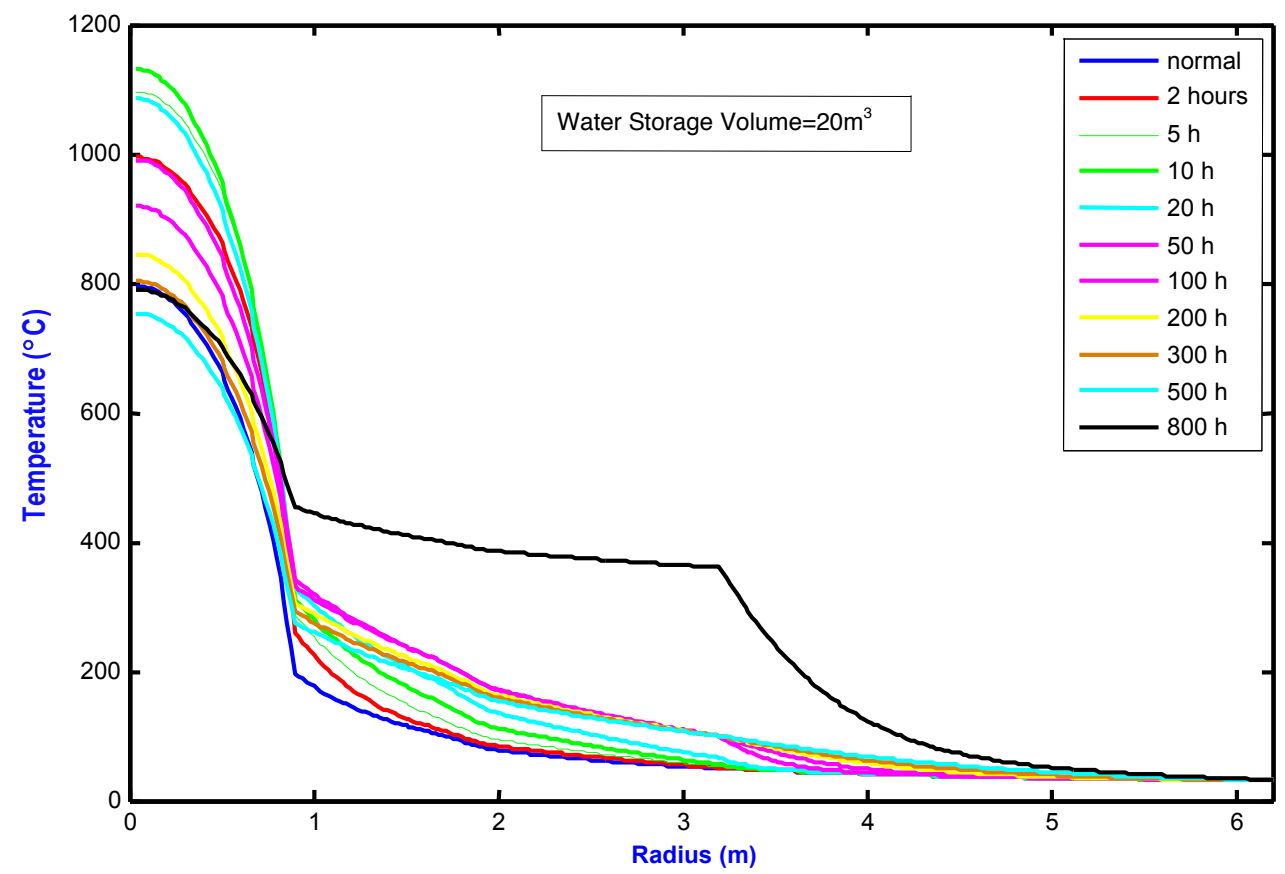

Figure 3. Radial temperature distribution across the reactor components starting from normal operation condition to 800 hours after SBO for the water volume of $20 \mathrm{~m}^{3}$. 
The evolution of maximum temperature of the core and other reactor components versus times is shown in Figure 4. The maximum core temperature reachs its peak of $1140{ }^{\circ} \mathrm{C}$ at around 12 hours after reactor trip and decreases again to $900{ }^{\circ} \mathrm{C}$ in 100 hours, and then it increases again very slowly until $920^{\circ} \mathrm{C}$ at 800 hours. For the reflector, the peak temperature is $350{ }^{\circ} \mathrm{C}$ at 30 hours, and decreases until $320^{\circ} \mathrm{C}$ while the water is still available, and then increases significantly until $6800^{\circ} \mathrm{C}$ at 800 hours. This temperature pattern is also followed for the maximum temperature of vessel and the concrete wall. The peak temperature of the vessel is $220^{\circ} \mathrm{C}$ at 60 hours and decreases until 200 ${ }^{\circ} \mathrm{C}$ while the water is available and increase significantly until $640{ }^{\circ} \mathrm{C}$ at 800 hours after the water lost totally. According to the maximum temperature of the concrete, it is assumed same with the water temperature inside the panel. In the beginning, the temperature rises until the saturation temperature of $100{ }^{\circ} \mathrm{C}$ and remaining constant at this temperature while the water is still available. After the storage water being empty the concrete temperature increases rapidly until $670{ }^{\circ} \mathrm{C}$ at 800 hours after SBO.

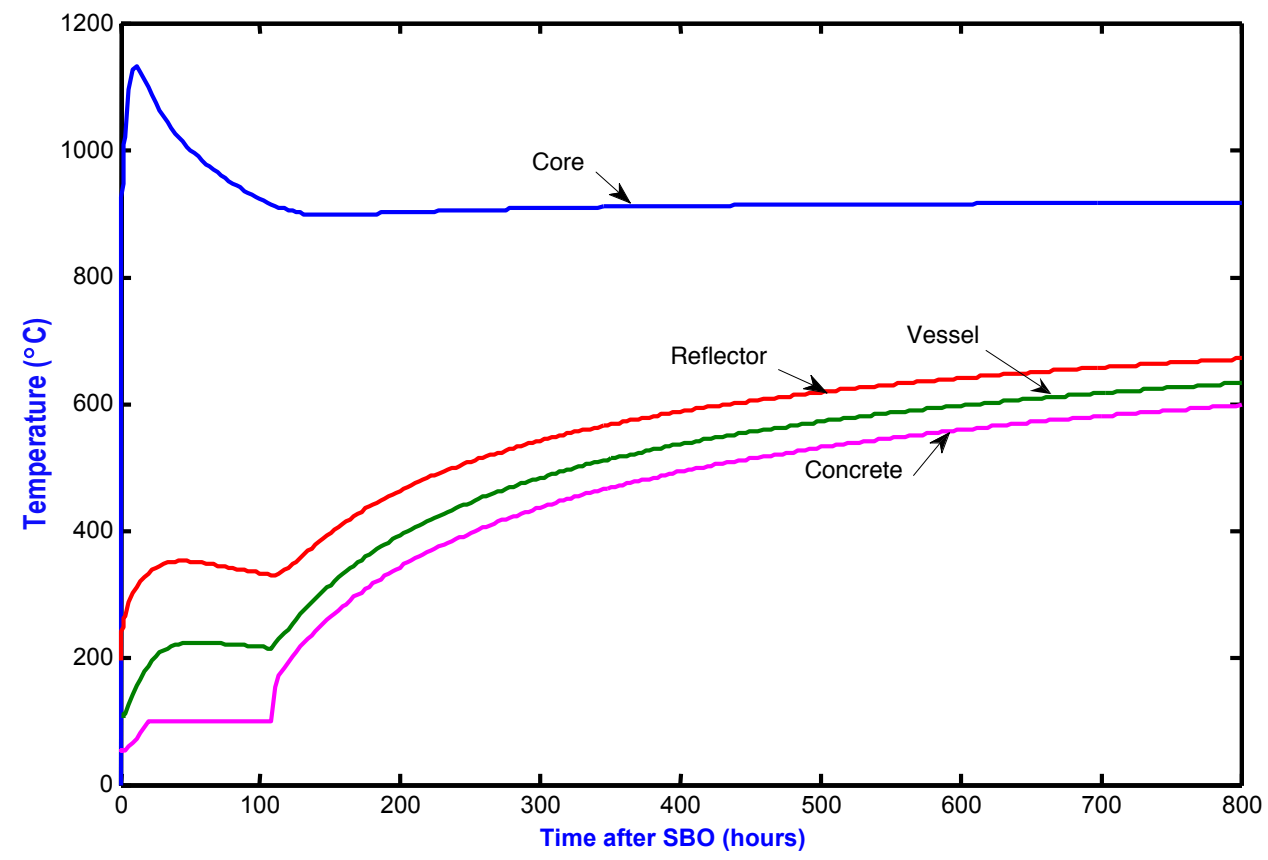

Figure 4. Maximum temperature of reactor components versus times

The influence of water volume to maximum concrete wall temperature is shown in Figure 5. In this case, because of the water panel position is too closed to the inside wall surface, the maximum temperature of the concrete wall is assumed to be same with the water panel temperature. There are 4 different water volumes to be considered in this study, such as: $5 \mathrm{~m}^{3}$, $10 \mathrm{~m}^{3}, 15 \mathrm{~m}^{3}$ and $20 \mathrm{~m}^{3}$. The result shows that in the beginning of $\mathrm{SBO}$, the wall concrete temperature increases until the saturated water temperature of $100{ }^{\circ} \mathrm{C}$, the time needed for this process is linearly proportional to the water volume. While the water is still available, the maximum concrete temperature remains constant at the saturated temperatur of $100^{\circ} \mathrm{C}$. When the water is no more available, the concrete temperature increases rapidly following the increase of panel temperature. For the volume of $5 \mathrm{~m}^{3}$, the maximum temperature of the concrete could reach $600{ }^{\circ} \mathrm{C}$ which could decrease its integrity. A study done by Achmad I.A. and Aras A.H. shows that at the temperature of $200{ }^{\circ} \mathrm{C}$, the concrete strength decreases to $85 \%$ of the strength at normal temperature condition [16]. As the availability of water is excessive, thus the available time is longer before temperature increases, so that the availibility of water is the important key for the safety of RDE in the long term SBO. Increasing the internal surface of the concrete is followed by increasing moderately the temperature of external surface as shown in the Figure 6 . 
At 800 hours after $\mathrm{SBO}$, the maximum increase of the external surface temperature is only less then $8{ }^{\circ} \mathrm{C}$.

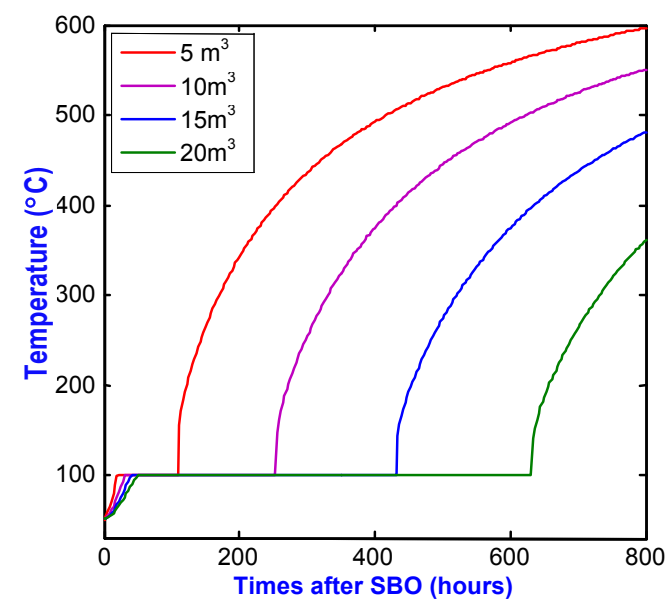

Figure 5. Effect of water volume to the evolution of concrete internal surface temperature

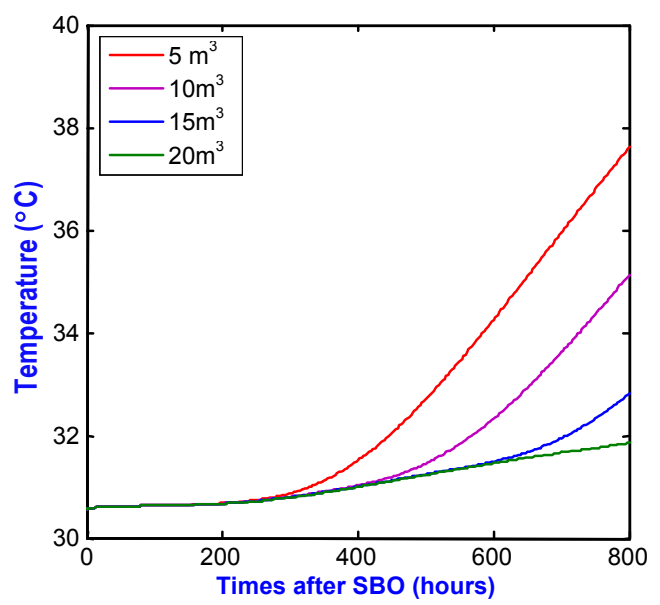

Figure 6. Effect of water volume to the evolution of concrete external surface temperature

For supporting the evaluation of thermal design, the influence of concrete wall thickness to its internal surface temperature evolution until 800 hours after SBO is shown in Figure 7. According to external wall surface temperature, it is shown in the Figure 8. The wall thickness is varied from $0.3 \mathrm{~m}$ to $3 \mathrm{~m}$, the volume of water is $5 \mathrm{~m}^{3}$ in this study. Its is shown that just after the water storage tank is empty, the temperature increases rapidly. The thicker is the concrete wall, thus the higher is the increasing of its internal surface temperature. Inversely for the external wall surface, the temperature decreases with the increasing of wall thickness. It is shown that the role of the concrete wall is considered as a thermal resistance against the decay heat transfered to the environment. The thermal resistance increases with the thickness, so that the temperature difference between internal and external surface also increases. For the wall thickness of $0,3 \mathrm{~m}$, the temperature difference between the two surfaces is around $200{ }^{\circ} \mathrm{C}$, and for $3 \mathrm{~m}$ of thickness, the temperature difference is $560{ }^{\circ} \mathrm{C}$ at 800 hours.

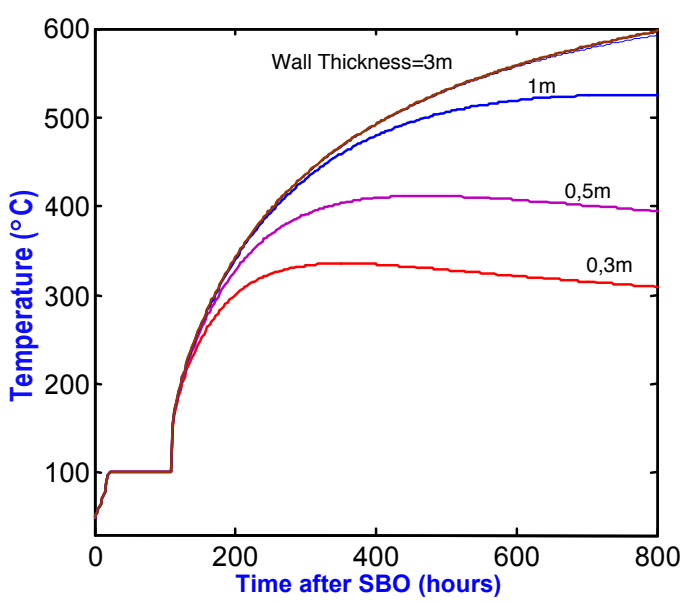

Figure 7. Effect wall thickness to the evolution of internal surface temperature

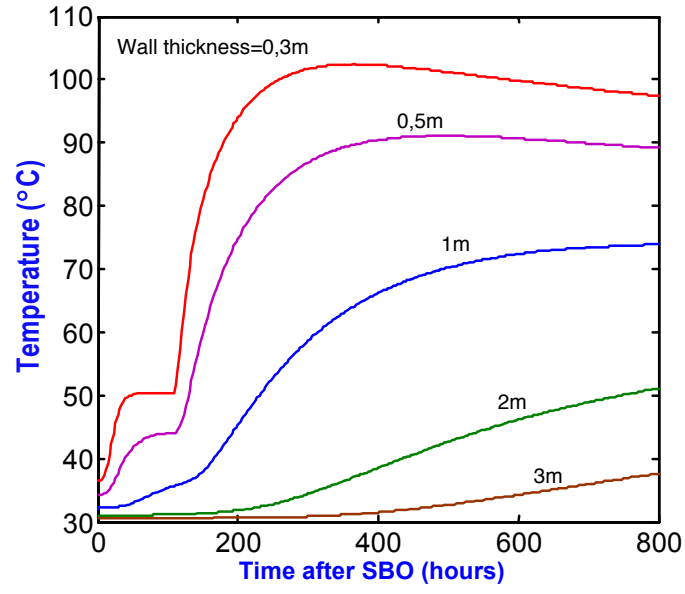

Figure 8. Effect of wall thickness to the evolution of external surface temperature

Figure 8 shows the evolution of heat power evacuated from each component of RDE for the wall thickness of $3 \mathrm{~m}$, starting from the reactor core, the reflector, the pressure vessel, the cavity and evacuated from the external surface of concrete wall. It is shown that the pattern of decreasing heat power from the core is practicaly identical than the patern of the decay heat decreasing it self. 
The heat evacuated from the reflector, the vessel and the cavity increase with time in the beginning and decrease again following with the decresing of the decay heat. While the water is available within the 100 hours after SBO, there is a significant difference between the heat evacuated by the vessel to the cavity and one by the cavity panel to the concrete wall. That large difference is due to the absorption of the majority of heat by the water in the panel to be transported to the water storage tank. After losing all of the water in the panel, the heat evacuated by the cavity to the concrete wall increase immediately inducing the increase of concrete wall temperature. In consequence, the heat evacuated by the vessel to the cavity through radiation mechanism decreases immediately with increasing the wall temperature.

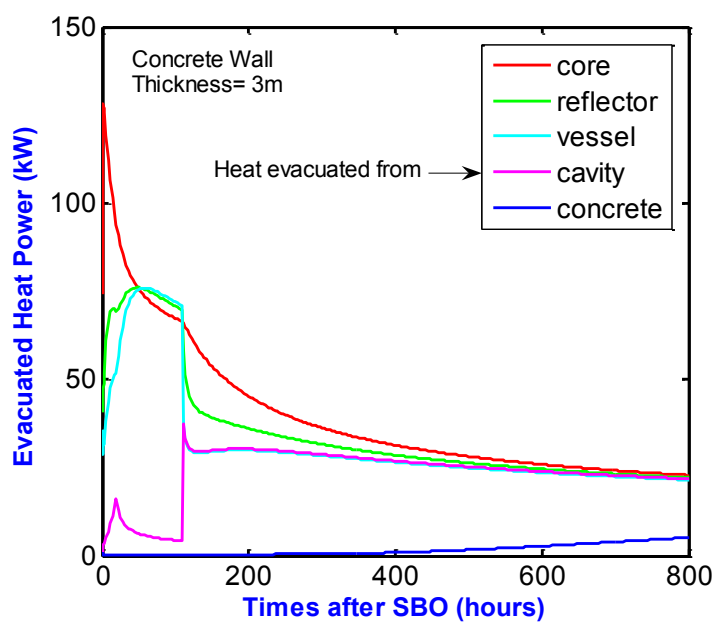

Figure 9 . Heat evacuated by reactor component versus time for the concrete wall thickness of $3 \mathrm{~m}$

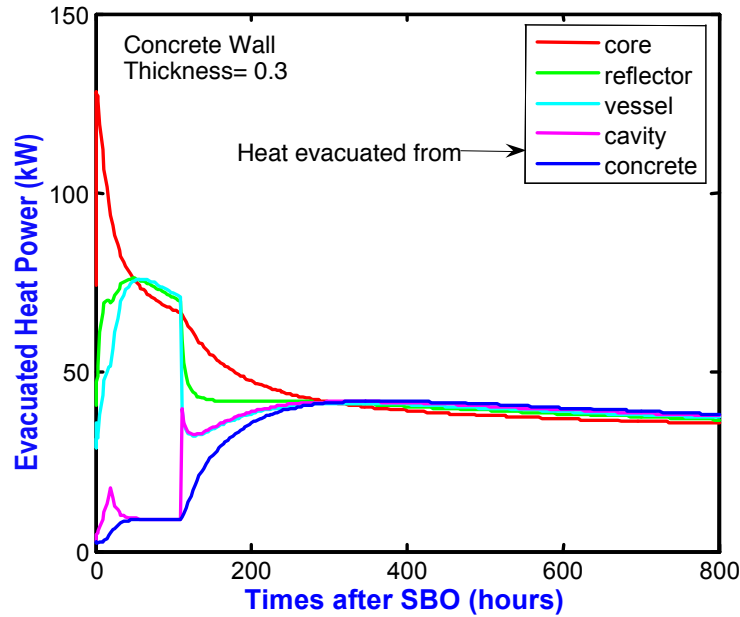

Figure 10. Heat evacuated by reactor component versus time for the concrete wall thickness of $0.3 \mathrm{~m}$

With the wall thickness of $3 \mathrm{~m}$, the heat evacuated by the external concrete wall to the air surrounding is still very low at 800 hours due to the long time needed to diffuse the heat across the wall. The difference of heat evacuated between the heat entering and leaving the concrete wall at 800 hours shows that the increase of concrete temperature is still continuing to occur. This heat difference does not appear in the case of wall thickness of $0.3 \mathrm{~m}$ as shown in Figure 10. With this much thinner wall, the heat diffuses more rapidly to the external surface of the concrete, so at 350 hours after SBO, the heat leaving the concrete wall exceeds the heat entering to the concrete. That induces the decrease of concrete wall temperature after 350 hours as shown in Figure 7 and Figure 8 for the wall thickness of $0.3 \mathrm{~m}$.

\section{CONCLUSION}

The study results the pattern of temperature across the core and other reactor components of $\mathrm{RDE}$ for several times until 800 hours after SBO. The core temperature reachs the maximum of $1140{ }^{\circ} \mathrm{C}$ at 12 hours after SBO, the maximum temperature is still below the safety limit of $1600{ }^{\circ} \mathrm{C}$ for pebble bed reactor. Increasing the volume of water could increase the safety level of RDE by delaying the time before rapidly increase the temperature of reactor components. Increasing the thickness of concrete wall will increase the temperature difference between two surfaces of the wall. The most important thing to be considered for the reactor safety especially in the case of longterm SBO or long-term loss of flow accident is maintaining the availability of water in the water storage of RHRS. 


\section{ACKNOWLEDGEMENT}

Acknowledgement is addressed to Center for Nuclear Reactor Technology and Safety for providing financial support in performing this research through the DIPA of 2016, and to Mr.Surip Widodo for his contribution in providing the necessary technical data.

\section{REFERENCES}

1. Lommers L.J., Mays B.E., Shahrokhi F. Passive heat removal impact on AREVA HTR design. Nucl. Eng. Des. 2014. 271:569-77.

2. $\quad$ Zhang Y.P., Qiu S.Z., Su G.H., Tian W.X. Design and transient analyses of emergency passive residual heat removal system of CPR1000. Nucl. Eng. Des. j. 2012. 242:247-56.

3. Zhou T., Chen J., Luo F., Cheng W. Fuzzy PSA evaluation method for passive residual heat removal system . Nucl. Eng. Des. 2012. 247:230-5.

4. Sambuu O., Obara T. Comparative study on HTGR designs for passive decay heat removal. Prog. Nucl. Energy. 2014.

5. Cheng Y.E., Yong W., Zhongming Q.I.U. Study on the long-term passive cooling extension of AP1000 reactor. Nucl. Sci. Tech. 2013. 24:1-7.

6. Sui Z., Sun J., Wei C., Ma Y. The engineering simulation system for HTR-PM. Nucl. Eng. Des. 2014. 271:479-86.

7. Strydom G., Gougar H.D. Preliminary reactor physics assessment of the HTR module with $14 \%$ enriched UCO fuel. Nucl. Eng. Des. 2013. 256(August 2011):304-21.

8. Zhang Y., Qiu S., Su G., Tian W. Progress in Nuclear Energy Design and transient analyses of emergency passive residual heat removal system of CPR1000 . Part I : Air cooling condition. Prog. Nucl. Energy. 2011. 53(5):471-9.

9. Zhang Z., Dong Y., Li F., Zhang Z., Wang H., Huang X., et al. The Shandong Shidao Bay 200 MWe High-Temperature Gas-Cooled Reactor Pebble-Bed Module (HTR-PM) Demonstration Power Plant: An Engineering and Technological Innovation. Engineering. 2016. 2(1):112-8.

10. Lv Q., Wang X., Kim I.H., Sun X., Christensen R.N., Blue T.E., et al. Scaling analysis for the direct reactor auxiliary cooling system for FHRs. Nucl. Eng. Des. 2015. 285:197206.

11. Yamoah S., Akaho E.H.K., Ayensu N.G.A., Asamoah M. Analysis of Fluid Flow and Heat Transfer Model for the Pebble Bed High Temperature Gas Cooled Reactor. Res. J. Appl. Sci. Eng. Technol. 2012. 4(12):1659-66.

12. Su J., Sik H., Keun C., Man J., Venneri F. Thermal-fluid characteristics of the transuranics fuel in a deep-burn HTR core. Nucl. Eng. Des. 2011. 241(9):3867-78.

13. Incropera F.P., De Witt D.P. Fundamentals of Heat and Mass Transfer. Canada:John Wiley \& Sons, Inc.; 1990.

14. Fu W., Li X., Wu X., Zhang Z. Investigation of a long term passive cooling system using two-phase thermosyphon loops for the nuclear reactor spent fuel pool. Ann. Nucl. Energy. 2015. 85:346-56.

15. Irwanto D., Obara T. Decay heat removal without forced cooling on a small simplified PBR with an accumulative fuel loading scheme. Ann. Nucl. Energy. 2013. 60:383-95.

16. Ahmad I.A., Aras A.H., Taufieq N.A. The effect of temperature to concrete strength analysis (in bahasa). 2009. 16(2):63-70. 